\title{
The Human Right to Benefit from Advances in Science and Promotion of Openly Accessible Publications
}

\author{
Alf Butenschøn Skre \\ Student, Master of Laws, University of Oslo, Executive Adviser, Forum for International Criminal and \\ Humanitarian Law. Email: abutenschon@gmail.com
}

Asbjørn Eide

Emeritus Professor, Norwegian Centre of Human Rights, University of Oslo. Email: asbjorn.eide@nchr.uio.no

\begin{abstract}
The article adopts a human rights perspective on the advent and proliferation of open access publishing models and policy goals, focusing primarily on the human right of everyone to benefit from progress in science and technology. While there is still room for developing more tenable and clear norms and delineating rights and obligations of individuals and states respectively in this regard, it is shown that states have an obligation to ensure the realisation of this right, and that there is a developing understanding of this obligation to include the promotion of open access to scientific knowledge. In an effort to further the discussion on open access publication, concrete examples of implementation of the principles of open access are presented and discussed.
\end{abstract}

Keywords: Right to Science; Right to Enjoy the Benefits of Scientific Progress; Public Good; Open Access; Scientific Publishing; Rights of Authors 


\section{Introduction: A Movement Towards Open Access}

In December 2001, the Open Society Foundation convened a meeting in Budapest. Its participants were academics from a number of disciplines, activists, librarians and publishers, with involvement in and experience from projects aimed at strengthening public access to scientific knowledge.

Earlier that year, an open letter to scientific publishers, signed by some 34,000 scholars and other professionals called for an online resource for free access to research and scholarly discourse in medicine and the life sciences, and other initiatives within academic disciplines or locally at institutions had been formed. ${ }^{1}$

The purpose of the meeting in Budapest was to explore possibilities for synergies and cooperation between initiatives for access to research results, and to establish a common set of universal principles for open access.

The declaration that resulted from the meeting may be seen as an important step in the formation of an international movement, across academic disciplines, aimed at improving access to scientific publications through the Internet, which is now generally referred to as the open access movement. ${ }^{2}$

Moreover, the declaration marked a turning point in that it provided a comprehensive definition of the contents and scope of the term open access, a definition that has since become widely adopted - albeit with minor variations - in the academic discourse as well as in policy documents. The third section of the Budapest Declaration reads:

\footnotetext{
1 Public Library of Science, 'Early History' <http://www.plos.org/about/what-is-plos/early-history/> accessed 1 June 2013.

2 The Budapest Declaration <http://www.budapestopenaccessinitiative.org/read> accessed 25 May 2013.
} 
The literature that should be freely accessible online is that which scholars give to the world without expectation of payment. Primarily, this category encompasses their peer-reviewed journal articles, but it also includes any unreviewed preprints that they might wish to put online for comment or to alert colleagues to important research findings. There are many degrees and kinds of wider and easier access to this literature. By "open access" to this literature, we mean its free availability on the public internet, permitting any users to read, download, copy, distribute, print, search, or link to the full texts of these articles, crawl them for indexing, pass them as data to software, or use them for any other lawful purpose, without financial, legal, or technical barriers other than those inseparable from gaining access to the internet itself. The only constraint on reproduction and distribution, and the only role for copyright in this domain, should be to give authors control over the integrity of their work and the right to be properly acknowledged and cited (emphasis added). ${ }^{3}$

Shortly after the Budapest Declaration, the adoption of two similar declarations in 2003 - the Bethesda Statement on Open Access Publishing ${ }^{4}$ and the Berlin Declaration ${ }^{5}$ - firmly established the term "open access".

Since 2003, several thousand open access journals have mushroomed across most academic disciplines and geographic locations. ${ }^{6}$ Online repositories containing scientific articles and datasets have been made immediately available to members of the general public with an Internet connection. One initiative which forms part of this movement, referred to by

\footnotetext{
$3 \quad$ Ibid.

4 Bethesda Statement on Open Access Publishing <http://legacy.earlham.edu/ peters/fos/bethesda.htm> accessed 1 June 2013.

5 The Berlin Declaration <http://oa.mpg.de/lang/en-uk/berlin-prozess/berliner-erklarung/> accessed 1 June 2013.

6 Finch Group, 'Accessibility, Sustainability, Excellence: How to Expand Access to Research Publications: Report of the Working Group on Expanding Access to Published Research Findings' (16 July 2012) para. 3.38.
} 
some as the academic spring, ${ }^{7}$ has organised more than 13,600 researchers in an academic boycott against one major publisher, which entails that the researchers undertake not to publish, referee or do editorial works for the publisher's journals, on grounds that the publisher maintains unnecessary barriers to the free exchange of information. ${ }^{8}$

Moreover, the goal of free open access to scientific results is gradually appearing in science policy white papers and legislation in several major academic world powers, including in the United States on federal and state levels, and in European Union institutions and European states. ${ }^{9}$

In sum, the open access movement has changed, and will in all likelihood continue to change, the ways in which scientific knowledge is disseminated, and the ways in which we think about publishing.

This article adopts a human rights perspective on the advent and proliferation of open access publishing models and policy goals, focusing primarily on the human right of everyone to benefit from progress in science and technology. This is an established human right set out in the International Covenant on Economic, Social and Cultural Rights (ICESCR) article 15(1)(b) and in several other human rights instruments, originally derived from the Universal Declaration on Human Rights (UDHR) article $27{ }^{10}$

The purpose of the present article is to contribute to the ongoing debate on open access by presenting a human rights based approach to issues regarding open access presently under

\footnotetext{
7 See for example 'The Price of Information' The Economist (Online 4 February 2012) <http://www.economist.com/node/21545974> accessed 1 June 2013.

8 See <http://thecostofknowledge.com/> (accessed 1 June 2013) for more information about the boycott. $9 \quad$ See section III.2.iv below.

${ }^{10}$ International Covenant on Economic, Social and Cultural Rights (adopted 16 December 1966, entered into force 3 January 1976) 993 UNTS 3, UN Doc A/6316 (ICESCR); Universal Declaration of Human Rights (adopted 10 December 1948) UNGA Res 217 A(III) (UDHR).
} 
discussion, and by offering and discussing concrete examples of the implementation of open access principles.

\section{Approaching Open Access as a Human Right: What Does it Entail?}

\section{Human Rights as a Public Good: State Duties}

Being recognised as a human right, the right to benefit from progress in science and technology is here treated as a public good. We will not in this context associate that term ("public good") with the way in which economic theory deals with public goods versus private goods and club goods. Economic theory operates in a different theoretical framework. Some authors, such as Kaul and Mendoza have critically examined theories about public and private goods and have argued that they are social constructs that depend on choices made by policy-makers and societies. ${ }^{11}$

We leave that discussion aside here, but need to explain what is here understood by the statement that recogniSed human rights as such constitute public goods. It simply means that it is a public duty undertaken by states to respect and ensure human rights in question. This has been explicitly stated in the opening articles of relevant instruments such as the International Covenant on Civil and Political Rights article 2, the European Convention on Human Rights and Fundamental Freedoms article 1, and in other human rights instruments. ${ }^{12}$

This does not mean that the state necessarily has to provide the goods in question. It has been generally accepted, particularly by the Committee on Economic, Social and Cultural

\footnotetext{
11 Inge Kaul and Ronald U Mendoza, 'Advancing the Concept of Public Goods' in Kaul et al. (eds), Providing Global Public Goods: Managing Globalization (OUP 2003).

${ }^{12}$ International Covenant on Political and Civil Rights (adopted 16 December 1966, entered into force 23 March 1976) 999 UNTS 171 (ICCPR).
} 
Rights (CESCR) of the United Nations Economic and Social Council (ECOSOC), that state obligations operate on three levels:

1. The obligation to respect the freedoms and rights of the individual as long as these do not block the rights of others,

2. the obligation to protect the legitimate scope of the rights and freedoms of the individual against illegitimate third party interference, and

3. the obligation to fulfil the right.

The third level of obligations (to fulfil the right) is subdivided in two: the obligation to facilitate the enjoyment of a given right, and the obligation directly to provide the goods implicit in the right when everything else fails.

It is therefore fully possible that the realisation of certain rights consist both in respecting private goods, in protecting them within their legitimate reach, and in facilitating or providing public goods in the economistic sense of the terms.

Not all human rights can be fully and immediately realised at all times and by all states. Specifically with regard to economic, social and cultural rights, they have to be progressively implemented when the opportunities arise. The expanding possibilities to realise the rights depend on improvement in knowledge, emergence and expansion of relevant human resources, and on material and financial resources. This could be illustrated by the example of progressive realisation of the established right to all to the highest attainable standard of health, but for reasons of space that will not be further discussed here. 


\section{The Gradual Elaboration of Human Rights and their Relationships.}

The International Bill of Human Rights - which includes UDHR and the two main covenants - contains a wide range of human rights: civil, political, economic, social and cultural. As repeatedly emphasiSed by the United Nations General Assembly (UNGA) and strongly endorsed by the World Conference on Human Rights, all human rights are interdependent and interrelated and therefore indivisible. As expressed in the Vienna Declaration and Programme of Action, adopted at the Vienna World Conference for Human Rights in 1993, 'all human rights are universal, indivisible, interdependent and interrelated'. ${ }^{13}$ Moreover, the Vienna Declaration states that human rights must be treated 'globally in a fair and equal manner, on the same footing, and with the same emphasis'. ${ }^{14}$

The implication of this has been elaborated on by Eide in publication of the United Nations Educational, Scientific and Cultural Organization (UNESCO). ${ }^{15}$ He has pointed out that human rights can be interrelated in at least three different ways: positive interrelationship, where the enjoyment of one set of rights is a necessary or desirable condition for the enjoyment of another set, or a necessary component of another right; negative interrelationship, where extensive violations of one set of rights are likely to have a negative impact on other human rights; and an interrelationship of balancing, where the protection of different rights for different persons may require limitations to one set of rights in order to make possible the enjoyment of another set of rights. ${ }^{16}$ It will be discussed below how this impacts on the interrelationship between the rights contained in the abovementioned article 15 of the ICESCR.

\footnotetext{
$13 \quad$ Vienna Declaration, para. 5.

Ibid.

Asbjørn Eide, 'Interdependence and Indivisibility of Human Rights' in Yvonne Donders and Vladimir Volodin (eds), Human Rights in Education, Science and Culture (UNESCO and Ashgate 2007).

${ }^{16}$ Ibid 14-15.
} 
All human rights entail a duality between rights-holders and duty-holders, but many human rights have not yet been sufficiently clarified to know with precision what the rights and the duties are. When the UDHR was adopted in 1948, it was obvious to all that those rights were far from being enjoyed around the world. Presenting the list of rights contained in the Declaration as universal rights did not imply that the UNGA naively believed that these rights at that time existed in reality. What the UNGA did was therefore, as stated in the preamble of the Declaration, to proclaim the set of rights contained in the Declaration as a common standard of achievement for all peoples and all nations:

to the end that every individual and every organ of society, keeping this Declaration constantly in mind, shall strive by teaching and education to promote respect for these rights and freedoms and by progressive measures, national and international, to secure their universal and effective recognition and observance, both among the peoples of member States themselves and among the peoples of territories under their jurisdiction. ${ }^{17}$

From that time on, there has been a historically rich process in elaborating the contents of these rights and in expanding knowledge, human and material resources to realise the rights in practice. These efforts take time and are still ongoing. The ultimate aim is expressed in UDHR article 28, which states that everyone has a right to a social and international order in which the rights there listed can be fully realised.

In the UDHR itself, the rights were listed in very general terms and needed elaboration and clarification in order to know what the rights and the corresponding duties were. A major step forward in this regard was the adoption of the two covenants in 1966 which together

$17 \quad$ UDHR, preambular paragraph 8. 
covered the rights listed in the Declaration, one on civil and political rights, and the other on economic, social and cultural rights.

But more needed to be done to clarify their content. A major role in doing so has been performed by the committees established by the state parties or the United Nations to monitor and promote the implementation of the rights contained in the various instruments. These committees receive and examine reports by states on their implementation of the rights in each of those conventions. On the basis of experience gained they elaborate their understanding of how the different rights should be implemented. They do so through what is now called "general comments". These are receiving increasing importance in the elaboration and interpretation of human rights law. The general comments are not legally binding in the strict sense but they carry considerable weight in the interpretation of each of the rights. This is due to the process by which they have been elaborated. Firstly, they draw on the extensive material contained in state reports, which have indicated the possibilities and the obstacles in realising the different rights. Secondly, they draw on the discussions held between the members of the Committee and delegations from state parties each time the particular report of a country is examined. Thirdly, the committees engage states, international agencies as well as non-governmental organisations in a discussion that includes the examination of drafts over several sessions. As a consequence, the resulting general comments, prepared by experts from different parts of the world, are based on extensive weighing of arguments and considerations and therefore carry high authority.

\section{The Human Right to Benefit from Advances in Science}

The primary focus of this contribution is ICESCR article 15(1)(b). The full text of article 15 is as follows:

1. The States Parties to the present Covenant recognize the right of everyone: 
(a) To take part in cultural life;

(b) To enjoy the benefits of scientific progress and its applications;

(c) To benefit from the protection of the moral and material interests resulting from any scientific, literary or artistic production of which he is the author.

2. The steps to be taken by the States Parties to the present Covenant to achieve the full realization of this right shall include those necessary for the conservation, the development and the diffusion of science and culture.

3. The States Parties to the present Covenant undertake to respect the freedom indispensable for scientific research and creative activity.

4. The States Parties to the present Covenant recognize the benefits to be derived from the encouragement and development of international contacts and cooperation in the scientific and cultural fields. ${ }^{18}$

The CESCR has issued general comments providing guidance in the application of Article 15 paragraphs (1)(a) ${ }^{19}$ and (1)(c) ${ }^{20}$, but has still not reached paragraph (1)(b). It has, however, expressed an intention to issue such a separate general comment sometime in the future. ${ }^{21}$

Some scholars who have sought to clarify the scope and content of this provision have relied on the drafting history and traveaux preparatoires of Articles 27 UDHR and 15 ICESCR, subsequent declarations by the UNGA, UNESCO instruments, and to some extent

\footnotetext{
$18 \quad$ ICESCR art 15.

CESCR, 'General Comment No. 21, right of everyone to take part in cultural life' (2009) UN Doc E/C.12/GC/21 (General Comment No. 21).

20 CESCR, 'General Comment No. 17, the right of everyone to from the moral and material interests resulting from scientific, literary or artistic production of which he or she is the author' (2005) UN Doc E/C.12/GC/17 (General Comment No. 17).

$21 \quad$ Ibid, para. 4.
} 
to the intentions of the drafters and signatory parties. ${ }^{22}$ With regard to developing tenable and clear norms and delineating rights and obligations of individuals and states respectively, which may be seen as a precondition for the effective realisation of the right, there is still room for further contribution in scholarly, legal and political discourse.

Recent additions that may further the understanding of this right, as we await the forthcoming general comment by the CESCR, are the Venice Statement on the Right to Enjoy the Benefits of Scientific Progress and its Applications, and, of particular importance in this regard, a report presented by the Special Rapporteur in the field of cultural rights, appointed by the UN Human Rights Council, on 'The right to enjoy the benefits of scientific progress and its applications'. ${ }^{23}$ The report grew out of a series of seminars and meetings and is likely to provide a significant input to the forthcoming general comment of the CESCR on article $15(1)(b)$.

Taken together, the Venice Statement and the report of the Special Rapporteur serve as important contributions to the discourse on the content of this right and could be indicative of the direction of the ongoing efforts of norm-clarification within the UN system.

In her report, the Special Rapporteur states that the right to science includes the following normative content:

1. access to the benefits of science by everyone, without discrimination;

2. opportunities for all to contribute to the scientific enterprise and freedom indispensable for scientific research;

3. participation of individuals and communities in decision-making; and

\footnotetext{
22 See for example William A Schabas 'Study of the Right to Enjoy the Benefits of Scientific and Technological Progress and its Applications' in Donders and Volodin (n 13); Lea Shaver, 'The Right to Science and Culture' (2010) Wisconsin Law Review 121.

${ }_{23}$ See UNCHR, 'Report by the Special Rapporteur in the field of cultural rights' (2012) UN doc $\mathrm{A} / \mathrm{HRC} / 20 / 26$.
} 
4. an enabling environment fostering the conservation, development and diffusion of science and technology. ${ }^{24}$

In particular elements (a) and (d) are relevant to the right to access scientific information.

In addressing the first of the four elements of the normative scope of article 15(1)(b), the Special Rapporteur notes that access to science must be to 'science as a whole, and not only to specific outcomes or applications'. ${ }^{25}$ In particular, the Special Rapporteur notes that '[a]ccess to scientific information for researchers is essential ${ }^{26}$ and 'notes with great interest the development of open-access journals and repositories, and the importance of mandatory open-access policies implemented by some universities and research institutions, ${ }^{27}$. The Special Rapporteur's understanding of the 'enabling environment' element, element (d), is largely based on an interpretation of article 15 paragraph 2. The Special Rapporteur noted that "Diffusion" encompasses the dissemination of scientific knowledge and applications both within the scientific community and in society at large, including through publishing research findings'. ${ }^{28}$

On this basis the Special Rapporteur recommends inter alia that states 'promote open access to scientific knowledge and information on the Internet ${ }^{29}$ and that states take steps necessary for the 'dissemination of scientific knowledge and applications both within the scientific community and society at large, ${ }^{30}$ The Special Rapporteur also recommends that ' $[\mathrm{u}]$ niversities, research and funding institutions adopt mandatory open-access policies for journals and repositories of research'. 31

Ibid, para 25.

Ibid, para 26.

Ibid, para 28

Ibid.

Ibid, para 48.

Ibid, para 74(c).

Ibid, para $74(\mathrm{j})$.

Ibid, para 74(d). 


\section{The Right to Protection of Authors' Material and Moral Interests}

For the purposes of this article, it is not necessary to discuss at length the scope of protection of authors' interests provided by ICESCR a rticle 15(1)(c), because we are here dealing with publications for which the authors do not expect or demand other material compensation than a clear recognition that she/he is the author of the product. This can itself carry considerable material benefits in that it may be a condition for employment at a university or research institution, but that can be ensured also within systems of open access, which has also been strongly emphasised in the Budapest Declaration and the Bethesda Statement on Open Access Publishing.

Some words on this topic are nevertheless in place here. The right to 'benefit from the protection of the moral and material interests resulting from any scientific, literary or artistic production of which he is the author' as provided by article 15(1)(c) has been addressed by General Comment No. 17 (GC 17) issued by CESCR in 2005.

GC 17 has sought to clarify the scope of the right to protection of authors' interests. Some scholars, have interpreted paragraph $(1)(\mathrm{c})$ as an obligation for states to ensure adequate protection of intellectual property rights such as copyright. ${ }^{32}$ Authors are today generally accorded intellectual property rights to their work, typically in the form of copyrights, under national legislation and under international treaties such as the Berne Convention for the Protection of Literary and Artistic Works and the World Trade Organization Agreement on Trade-Related Aspects of Intellectual Property Rights (TRIPS).

The CESCR has pointed out that there is no congruence between intellectual property rights and the rights of authors under article 15(1)(c). On the contrary, there are inherent

\footnotetext{
32 See for example Paul LC Torremans, 'Copyright as a Human Right' in Paul LC Torremans (ed), Copyright and Human Rights: Freedom of Expression, Intellectual Property, Privacy (Kluwer 2004).
} 
differences between these terms. It is therefore important not to equate intellectual property rights with the human right recognised in paragraph (1)(c):

While under most intellectual property systems, intellectual property rights, often with the exception of moral rights, may be allocated, limited in time and scope, traded, amended and even forfeited, human rights are timeless expressions of fundamental entitlements of the human person. ${ }^{33}$

Moreover, the CESCR notes that while the human right

safeguards the personal link between authors and their creations and between peoples, communities, or other groups and their collective cultural heritage, as well as their basic material interests which are necessary to enable authors to enjoy an adequate standard of living, intellectual property regimes primarily protect business and corporate interests and investments. ${ }^{34}$

With regard to "moral rights", however, the CESCR adopts a definition that largely overlaps with the moral rights granted to authors under article 6bis of the Berne Convention.

As to the protection of "material" interests of authors under article 15(1)(b), GC 17 remarks that this right must be seen in connection with the right to own property as recognised in UDHR article 17 and in regional human rights instruments, as well as the right of any worker to adequate remuneration, as recognised in ICESCR article 11(1). ${ }^{35}$ More specifically, GC 17 states that ensuring adequate protection of material interests does not necessarily require that such rights are protected for the entire lifespan of the author. Other ways of enabling authors to enjoy an adequate standard of living are suggested in GC 17,

General Comment No. 17, para. 2.

Ibid.

Ibid, para 15. 
which could seem to indicate that a term of exclusivity for the author to exploit his production is not necessarily required for adequate protection of authors' material rights. ${ }^{36}$

\section{The Interrelationship between the Right to Science and the Rights of Authors:}

\section{A Balance between Access and Incentives for Innovation, or a Positive Interrelationship?}

As previously noted, human rights can be interrelated in at least three different ways: positive, negative and balancing interrelationship. Conceptualising the right to science as an obligation for states to promote the availability of knowledge as a de facto public good might appear to place it in tension with authors' material rights. Shaver argues that the development and expansion of the regime of intellectual property rights in the second half of the twentieth century, in particular through the adoption of TRIPS and the doctrine of "propertization of knowledge' that it entails, has undermined the goal expressed in UDHR article 27 of the development and dissemination of knowledge as a public good. ${ }^{37}$ Following a similar line of argumentation, the Special Rapporteur has in her abovementioned report recommended states to 'reconsider the current maximalist intellectual property approach'. ${ }^{38}$

On the other hand, some scholars claim that the protection of authors' material interests resulting from their creations, and intellectual property rights in general, are necessary in order to incentivise innovation. ${ }^{39}$ The purpose of intellectual property rights may be seen as ensuring that those who take the risk of investing in the sometimes costly and timeconsuming process of developing innovations will be able to enjoy the benefits of their investment.

See e.g. Keith E Maskus and Jerome H Reichman, 'The Globalization of Private Knowledge Goods and the Privatization of Global Public Goods' in Keith E Maskus and Jerome H Reichman (eds), International Public Goods and Transfer of Technology Under a Globalized Intellectual Property Regime (Cambridge University Press 2010) 6. The chapter is available online at <http://dx.doi.org/10.1017/CBO9780511494529.002> accessed 1 June 2013.
} 
Without protection of their material interests, scientists would be without incentive to take the risk of investing in the development of knowledge innovations. In this context one could recall that the right to science is understood by the Special Rapporteur in such a way that the state has an obligation not only to diffuse scientific knowledge, but also to ensure an enabling environment to foster the development of science. In this view, the right to protection of authors' material interests could be seen as a precondition to provide the public with access to scientific knowledge. Using Eide's terminology, the two rights - the right of everyone to benefit from the progress of science, and authors' material rights - could be seen to be in a positive relationship.

However, as argued by inter alia Benkler, the hypothesis of the "efficiency of regulating information, knowledge, and cultural production through strong copyright and patent' is both 'theoretically ambiguous' and 'lacks empirical basis' ${ }^{40}$ It is beyond the scope of the present article to evaluate the merits of this criticism, and the theoretical debate amongst economists and legal scholars. However, the strength of the positive interrelationship between the right to protection of authors' material interests and the right to science would necessarily be reduced if the validity of its supporting hypothesis is weakened.

\section{Authors' Material Rights are not in Question in the Open Access Discourse, but the Moral Rights are.}

As observed in the Budapest Declaration, and as will be discussed below, authors submit their articles to scientific journals, and transfer copyrights to such articles, without expectation of remuneration or royalties in return. In the words of Suber, the articles are 'donated' to the community of researchers. ${ }^{41}$ Thus, the prospect of exercising intellectual

\footnotetext{
$40 \quad$ Yochai Benkler, The Wealth of Networks: How Social Production Transforms Markets and Freedom (Yale University Press 2006) 37-40.

$41 \quad$ See Peter Suber, 'Creating an Intellectual Commons through Open Access' in Charlotte Hess and Elinor Ostrom (eds), Understanding Knowledge as a Commons (MIT Press 2007).
} 
property rights over one's innovation does not seem to be a necessary incentive for scientists to author and seek publication of such articles. The efforts invested by the scientist in the preparation of the research articles will most often be remunerated by salary from the scientist's institution or research grant that made her or his research possible. Hence, with regard to donated works such as journal articles, there could be a positive interrelationship between the right to science and the protection of authors' moral and possibly indirect material interests. The incentives of authors to obtain publication of an article would seem to be to achieve impact of the research results, and that other researchers are influenced by and cite their work, and to be recognised or further appreciated as a competent scholar in that field, which may entail career benefits. The more influential the journal an author is able to publish an article through, the more impact the article is likely to achieve. Such impact, in the form of attention, recognition and citations, will in turn be an advantage for the author when she or he applies for research grants or research positions and increase career opportunities.

Finally, as noted by some scholars, knowledge innovation builds upon and requires access to prior knowledge innovations. ${ }^{42}$ This may be formulated in a variety of ways, including the famous statement usually attributed to Isaac Newton: 'if I have seen farther it is because I stand on the shoulders of giants'. ${ }^{43}$ Access to knowledge, at least in theory, facilitates new innovations. This effect, known as the "standing on the shoulders of giants" effect or as "positive intertemporal spillovers of research and development", is reduced if there are barriers to access to scientific knowledge. In this way, the fulfilment of states' obligation to provide access to knowledge is linked with states' obligation to provide an enabling environment for scientific innovation. States should not by any means hamper

$42 \quad$ See e.g. Roberta Capello and Peter Nijkamp (eds), Handbook of Regional Growth and Development Theories (Edward Elgar Publishing 2009).

$43 \quad$ Reproduced and commented by Benkler (n 37) 37-38. 
scientific innovation through unnecessary or disproportional barriers against access to scientific knowledge.

\section{Practical Implementation of Open Access Publishing: Experiences and Themes for Further Discussion}

This section will focus on contemporary developments in the implementation of open access publishing. It does not seek to provide a blueprint for an optimal model for open access publishing, but to present achievements and highlight certain key issues, in an effort to contribute to and stimulate further exploration and discussion.

\section{The Role of the Internet and of Conventional Journals in Driving Open Access Initiatives}

The advent of the Internet has fundamentally changed the ways in which information is disseminated and received. While mass-dissemination of ideas in the past could require the preparation and distribution of printed materials by trained professionals - or media broadcasts - individuals may now, without costs other than those of a personal computer, electricity and an Internet connection, publish information (be it pictures, blog updates, articles) online in a way that potentially makes it available to millions of other users, and such channels of immediate and global mass communication have become a familiar part of everyday life for large parts of humanity.

These technological and cultural developments, including the dramatic reduction in the costs of disseminating information and the commonality of immediate free access to information online, have arguably led to a change in expectations facing publishers of conventional media, including conventional journals. As will be described below, these expectations are not met by the conventional journal model. 
By the term "conventional journal" is meant a periodical academic journal with the following features:

1. articles are provided to the journal by authors without remuneration. In other words, authors contribute do not demand or receive payment or royalty for their contribution. ${ }^{44}$

2. acceptance by the journal to publish articles generally requires the author to transfer copyrights to the journal. The author may or may not be granted limited usage rights to the text, such as the right to reuse the article for teaching purposes. ${ }^{45}$

3. members of the academic community peer-review submitted articles and sit on the journal's editorial board, without remuneration. ${ }^{46}$

4. published articles may be accessed in print and/or online only against a subscription fee (usually paid by academic institutions to provide access for their staff and students) or a one-time fee for access to individual volumes or articles (for persons without access through their institution).

The requirement of paid subscription or a one-time fee from readers should be recognised prima facie as a barrier to access to scientific knowledge. This access barrier is strengthened by the fact that the average yearly increase in the price for journal subscriptions in recent years have exceeded indicators such as the US consumer price index, and it also exceeds the adjustment of public library budgets. ${ }^{47}$ Even an institution such as the Harvard Library of Harvard University, possibly one of the most prestigious and best-funded research institutions in the world, finds that the subscription fee of some journals has increased so dramatically

\footnotetext{
$44 \quad$ Suber (n 38).

45 Elizabeth Gadd, Charles Oppenheim and Steve Probets, 'RoMEO Studies 4: an Analysis of Journal Publishers' Copyright Agreements' (2003) 16 Learned Publishing 293.

$46 \quad$ Suber (n 38).

47 Stephen Bosch and Kittie Henderson, 'The Winds of Change | Periodicals Price Survey 2013' Library Journal (Online 25 April 2013) <http://lj.libraryjournal.com/2013/04/publishing/the-winds-of-changeperiodicals-price-survey-2013/> accessed 30 May 2013.
} 
that the cost is prohibitive. Annual costs of Harvard University for journals were in 2012 reportedly approaching USD 3.75 million, with single journals costing up to USD $40,000 .{ }^{48}$ Doubts have been expressed as to whether such prices are proportionate to publishers' cost of production, as one publisher of some of the most prestigious and hence most expensive journals have reported operating profit margins of more than $36 \% .{ }^{49}$ Moreover, journals are sometimes "bundled" by publishers in such a way that it is necessary to subscribe to a group of (often less attractive) journals in order to gain access to the most prestigious journals, in a business model often referred to as 'big deals'. 50

When the Harvard Library and the libraries of other prestigious universities in the world find themselves unable to cover journal subscription fees, it is likely that many universities in less resourceful countries are effectively barred from accessing the knowledge published in many journals, leaving scientists at these institutions unable to take part in current developments in their academic disciplines. Some charitable initiatives, such as the World Health Organization's 'Health InterNetwork Access to Research Initiative'51 and Electronic Information for Libraries (EIFL) ${ }^{52}$ help libraries and not-for-profit organisations to gain access to otherwise unaffordable knowledge resources. However, such commendable initiatives are of a limited scope, and therefore only partially offset negative effects of the underlying structural deficit in conventional journal publishing.

\footnotetext{
48 --------, 'Faculty Advisory Council Memorandum on Journal Pricing: Major Periodical Subscriptions Cannot Be Sustained', The Harvard Library (Online 17 April 2012, <http://isites.harvard.edu/icb/icb.do?keyword=k77982\&tabgroupid=icb.tabgroup143448> accessed 1 June 2013. 49 See George Monbiot, 'Academic Publishers make Murdoch Look Like a Socialist' Guardian (Online 29 August 2011) <http://www.guardian.co.uk/commentisfree/2011/aug/29/academic-publishers-murdochsocialist>; Richard Monvoisin, 'Recherche publique, revues privées' Le Monde Diplomatique (Online December 2012) <http://www.monde-diplomatique.fr/2012/12/MONVOISIN/48501> accessed 1 June 2013.

$50 \quad$ See (n 45); ------, 'Of Goats and Headaches' The Economist (Online 26 May 2011) <http://www.economist.com/node/18744177> accessed 1 June 2013.

51 See http://www.who.int/hinari/about/en/ for more information.

52 See http://www.eifl.net/what-we-do for more information.
} 
As discussed above ${ }^{53}$ access to knowledge in society arguably strengthens innovation. The pricing practices of many conventional journal models, insofar as it leads to the exclusion of institutions and individuals from access to published knowledge through its pricing practices, could therefore in theory be regarded as a factor that reduces the total amount of innovation in the scientific community.

For many researchers, however, including the authors of this article, adequate access to scientific knowledge is often not as much of a concern as the danger of being overwhelmed by the number and volume of resources that are immediately available through the Internet and electronic resources of institutional libraries, a sensation often referred to as "overload" of knowledge or information. In this regard, journals, which sift manuscripts and reject those that do not fulfil the requirements of publication and improve accepted manuscripts through a process of review and revision prior to publication, help researchers to locate relevant and reliable resources amongst the cacophony of ideas, discussions and oddments that is the Internet. The process of peer-review as developed and organised by conventional journals, although it has been subject to some criticism, ${ }^{54}$ is arguably a defining and necessary feature of modern scientific publishing. In this way, the editorial work undertaken and coordinated by journals contributes to the scientific community.

However, the costs that publishers incur in carrying out this function do not necessarily have to be covered by readers. As will be discussed below, there are alternative models of publishing that arguably allow for the same type of quality control and editorial refinement as is currently provided by conventional journals, without creating a barrier to access by charging fees from readers.

\footnotetext{
$53 \quad$ See section II.6 above.

54 See e.g. Philip A Schrodt, 'If I ran the University...', <http://eventdata.psu.edu/7DS/7DS.University.chpt.pdf> accessed on 30 May 2013, 28-38.
} 


\section{Different Routes to Open Access, in Theory and in Practice}

\section{Variations in the Understanding of Open Access}

Although open access is defined in slightly different wording in the various statements and declarations made by open access initiatives, the following two requirements may be seen as a common denominator:

1. availability in digital form via the Internet, free of charge to the reader; and

2. absence of barriers in the form of intellectual property rights that block access and limit usage, except those necessary to enable authors to control the integrity of their work, and to ensure that they are properly acknowledged and cited. ${ }^{55}$

Variation in the understanding and application of open access is found mainly in the second requirement. Whereas the most extreme conceptions of open access publishing would require that all of the author's intellectual property rights are waived, most protagonists of open access argue that intellectual rights only have to be waived to the extent that readers may use the journal article for legitimate scholarly and non-commercial purposes, which could include downloading, printing and sharing the article, while the author should retain rights required to ensure her or his interests in being attributed for the work and to protect its integrity. In other words, the concept of open access is generally compatible with the right to protection of authors' moral interests resulting from his or her creation under article ICESCR 15(1)(c).

\section{Variations in Practical Implementation}

Whereas there is notable variation between the ways in which open access publishing is carried out, the open access discourse tends to focus on two different main models for the open access publishing of journal articles: the 'golden route' and the 'green route'. ${ }^{56}$

55 For a broader discussion of open access literature, see Suber (n 38). 
The 'golden route' entails publication through open access journals. These journals bear similarity to conventional journals in that they adopt similar measures for quality control of received articles, including peer-review and editorial selection. Studies show that open access journal articles on average are cited more often than articles in conventional journals put differently and perhaps slightly simplified, articles published in open access journals do not seem to be less citeable or leave a lesser impact on the scientific community than articles published in conventional journals. ${ }^{57}$ The crucial difference from conventional journals is that articles published in open access journals are made freely available on the Internet, in accordance with the requirements open access. The essential question for publishers of open access journals is how to cover the costs involved in producing the journal - to the same standards of quality as conventional journals - without relying on subscription revenues to cover the costs of such production. A substantial amount of experimentation has been conducted in order to find sustainable models, as will be described below. What will be presented is by no means an exhaustive overview of the ways in which open access journals may be financed. ${ }^{58}$

One way to finance open access journals is to charge authors - or rather their institutions or research funders - instead of charging readers. This is done by requiring an "author fee" from authors whose articles are accepted for publication. While much attention has directed to this way of financing open access journals, and it has been described as 'the

\footnotetext{
$56 \quad$ See for example the Budapest Declaration.

57 For an overview of studies on the 'open access citation advantage' phenomenon, see Alma Swan, 'The Open Access Citation Advantage: Studies and Results to Date' (unpublished 2010) <http://eprints.soton.ac.uk/268516/> accessed 30 May 2013.

58 The following works have been useful and may be recommended as further reading for readers with a particular interest in the business models of open access journals: John Willinsky, The Access Principle The Case for Open Access to Research and Scholarship (MIT Press 2006); Stevan Harnad 'No-Fault Peer Review Charges: The Price of Selectivity Need Not Be Access Denied or Delayed' D-Lib Magazine (Online July August 2010) <http://www.dlib.org/dlib/july10/harnad/07harnad.html>; Mark J Mccabe and Christopher M Snyder, 'Open Access and Academic Journal Quality' (2005) American Economic Review 453-459.
} 
most prominent form of immediate and unqualified open access to journals, ${ }^{59}$ some surveys show that less than half of all open access journals charge such fees, while the rest find alternative ways of financing or even eliminate costs entirely through voluntary contributions. ${ }^{60}$

The imposition of author fees could have inadvertent consequences for the contents of the journal. First, while it provides unlimited access for persons with an Internet connection to read articles, it could create a barrier for authors. There is arguably a developing practice of including author fees in research project budget proposals, and some institutions and research funders provide financial support to cover author fees. ${ }^{61}$ However, authors without such funds available will be required to plead with university administrators to secure the necessary funds from their institution's budget, or possibly cover the author fee out of their own pockets. For authors with no relevant financial means available, an author fee could therefore be a barrier to dissemination of their research. This barrier could lead to an uneven playing field for researchers, and it could in particular relegate researchers in materially speaking less resourceful countries from being contributors in the international academic discourse to become recipients of research produced in more privileged parts of the world. Suber writes that '[m]ost [open access] journals waive the fee in cases of economic hardship, ${ }^{62}$ which could offset this negative effect of author fees.

A second potential drawback is that as a result of a model based on author fees for accepted articles, it would be in the open access journal's short-term interest to publish as

\footnotetext{
$59 \quad$ Willinsky (n 55) 214.

60 See ------, 'What percentage of open-access journals charge publication fees?' The Occasional Pamphlet (Blog 29 May 2009) <http://blogs.law.harvard.edu/pamphlet/2009/05/29/what-percentage-of-openaccess-journals-charge-publication-fees/> accessed 1 June 2013.

$61 \quad$ For example, in June 2013 the University of Oslo (UiO) established a fund to cover open access fees for its researchers, see 'Nyopprettet publiseringsfond for UiOs forskere' ['Newly established publication fund for $\mathrm{UiO}$ researchers'] <http://www.ub.uio.no/om/aktuelt/aktuelle-saker/2013/publiseringsfond.html> accessed 17 June 2013.

$62 \quad$ Suber (n 38) 173
} 
many articles as possible, so that the journal could collect author fees from a higher number of authors than if it were more selective in its editorial process. In the longer term, journals that give in to that temptation would shoot themselves in the foot, as the quality of accepted articles would likely be lower, and the reputation of the journal - arguably its most important asset to attract high quality article submissions - would likely deteriorate.

To reduce or avoid these negative effects of author fees, it has been suggested that journals should not charge a fee for accepted articles, but rather charge processing fees from authors who submit articles for peer-review, whether or not the article is accepted, and charge authors of accepted submissions an additional fee covering the marginal cost the journal incurs in connection with acceptance and publishing an article. ${ }^{63}$ This alternative model of financing would distribute the cost of journal production amongst a larger number of authors, and reduce - but not eliminate - the cost barrier for authors. It would also reduce the theoretical short-term incentive for journals to accept a high number of articles for publication in order to increase revenues.

Another way of covering the costs of open access journals is through subsidisation. This is done in a variety of ways, through financial support by sponsors and through in-kind support. For example, a university may host and publish an open access journal, and task its researchers and other staff to perform editorial and administrative tasks for the journal. ${ }^{64}$ While this model has the advantage of providing free access for readers without a cost barrier for authors who wish to submit articles, certain weaknesses could theoretically arise as a result of monolithic and/or voluntary source of contributions, including pressures on editorial and scientific independence and stability.

\footnotetext{
$63 \quad$ Harnad (n 55); Mccabe and Snyder (n 55)

64 Suber (n 38) points to the Philosopher's Imprint, published by the University of Michigan, as an example on p. 174.
} 
Yet another way of covering the costs of open access journals is through solutions that may be regarded as a "hybrid" between the conventional journal model and open access. Such solutions include, firstly, conventional journals that make individual articles openly accessible online if the author pays a special author fee, while other articles are only available to readers against subscription or pay-per-view fee. This approach brings with it the drawbacks of the author fee open access journal model as described above. Secondly, some journals make a small portion of their articles openly accessible as a marketing move, in order to spark interest in the journal and seize readers via the Internet. While such strategies in effect provide free online access to publications, they rely on an economic marked analysis, and are not directly linked to the goal and concept of open access. A third hybrid model is to finance online open access through subscription fees charged for the printed edition. While this hybrid model avoids the drawbacks associated with author fee-based models and subsidies as described above, it could be argued that the importance of printed versions of publications is losing ground to electronic versions.

In sum, there are several open issues for further development and experimentation in the financing of open access journals. As put by Suber, 'there is not just one way to cover the expenses of a peer-reviewed [open access] journal, and we have a long way to go before we can say that we have exhausted our cleverness and imagination' ${ }^{65}$ While economic theory may contribute to the development of business models for open access journals that are sustainable and ensure high scientific quality, it is important to maintain focus on the dissemination of knowledge as a public good and a human right, in the further exploration in this field.

The other main model for providing open access to journal articles, known as the 'green route', is through open access repositories, sometimes referred to as archives. Repositories, $65 \quad$ Ibid. 
in contrast to journals, do not necessarily conduct peer-review or other forms of quality control of the published articles, and are sometimes open for submissions by authors for immediate publication. There is a great deal of variation with regard to the roles and policies of repositories. Some repositories are created by institutions for the purpose of making as much as possible of the scientific production of the institution's staff openly available. ${ }^{66}$ Other repositories, such as $\operatorname{PLOS}^{67}$ and $\mathrm{SSRN}^{68}$, do not have an institutional focus, but focus on particular academic disciplines and include contributions from academics within that discipline worldwide. A set of common standards for repositories, such as those developed by the Open Archives Initiative, ${ }^{69}$ may ensure interoperability between repositories and enhance the dissemination of their contents to an as wide as possible audience.

Although they normally do not include mechanisms for quality control, open access repositories may play an important role in making knowledge openly accessible en masse. In particular, it is a valuable channel for making articles that have already been qualitycontrolled and accepted for publication by a conventional journal freely available, when this is done in compliance with copyright regulations and relevant agreements between the author and the publisher. Many authors chose to reserve vis-à-vis their publisher the right to use published articles for non-commercial purposes, including the right to submit their article to an open access repository. To facilitate such reservations, also by authors who are not necessarily proficient in the "legalese" of publication agreements, protagonists of open access have developed standardised addendums. ${ }^{70}$

\footnotetext{
66 See for example Digital Access to Scolarship at Harvard, at <http://dash.harvard.edu/>. See <http://www.plos.org/>.

See <http://ssrn.com/>.

See <http://www.openarchives.org/>.

See for example 'Addendum to Publication Agreement', available at <http://www.sparc.arl.org/sparc/bm doc/Access-Reuse_Addendum.pdf> accessed on 1 June 2013.
} 


\section{The Case for Access to Legal Scholarship - Contributing to Rule of Law}

Adequate access to legal texts, including legislation, regulations, court decisions, is arguably a prerequisite for members of society to fully understand their legal rights and duties. Under most national copyright legislation, texts produced by public bodies, including legislation, judgments and other legal documents are not subject to copyright, ${ }^{71}$ and states take steps to make the contents of such texts publicly known.

In the words of Danner, legal scholarship 'serves to support and to influence the professional work of judges, lawyers, and legal scholars and to explain the law to the public'. ${ }^{72}$ The importance of legal scholarship varies in different legal traditions and jurisdictions. As Danner notes, at least in civil law countries, lawyers 'rely on legal journals both as sources for the full texts of decisions and for annotations discussing their significance' ${ }^{73}$ In such jurisdictions, the public would arguably have a particularly strong interest in developing open access channels for publishing legal journals, in that it increases access to factors that shape the legal order.

Open access to scholarship in international human rights law and international criminal law could be particularly valuable in that it may empower national authorities and non-state actors, especially in materially speaking less resourceful countries, in their efforts to confront human rights violations and to investigate, prosecute and adjudicate cases of such violations. In this perspective, open access could contribute to the strengthening of rule of law, which is a crucial prerequisite for developing and maintaining respect for human rights in society.

\footnotetext{
71 The exceptions are notably the United Kingdom and some Commonwealth countries, who maintain the concept of 'Crown Copyright'. See for example J A L Sterling, 'Crown Copyright In The United Kingdom And Other Commonwealth Countries' (1996) 10 Intellectual Property Journal 157.

72 See Richard A Danner, 'Applying the Access Principle in Law: The Responsibilities of the Legal Scholar' (2007) 35 International Journal of Legal Information 355, 366.

73 Ibid, 369.
} 
In the field of international criminal and humanitarian law, the Torkel Opsahl Academic EPublisher (TOAEP) has served as a groundbreaker for open access publishing. TOAEP, which is named after the late international and constitutional law expert and pioneer, is a non-profit publisher established by the Centre for International Law Research and Policy (CILRAP), 'firmly committed to open access publishing', which actively seeks to provide access to knowledge for legal professionals. ${ }^{74}$ In addition to edited volumes and monographs, TOAEP also publishes an Occasional Papers Series and policy briefs on selected issues in international law. Some of TOAEPs publications are based on seminars organised by the Forum for International Criminal and Humanitarian Law (FICHL), another department of CILRAP, which 'aims to identify, frame and host discourses on key issues in international criminal and humanitarian law, transitional justice and in law more widely'. ${ }^{75}$ In this way, there is a synergy between FICHL and TOAEP, which facilitates wide and open access dissemination of the output of FICHL's activities, thereby optimising impact and value.

TOAEP publications are freely available online through the publisher's website, while printed versions may be purchased online. The price of the printed versions isvirtually equal to the incremental cost of production and distribution of the purchased copy. Therefore, TOAEP's model of publishing should not be regarded as a case of the "hybrid" way of financing online open access through the price of printed subscription, as described above. The motivation for distributing low-cost printed materials is in recognition that the format of printed publications is important to provide equal and global access to readers, including those relying on traditional libraries and collections, institutional or private. ${ }^{76}$

TOAEP has been able to produce and disseminate its publications online without cost to the reader, due to several factors, including use of information technology tools and 
organisation of administrative support in ways that cut costs in the performance of substantive functions in the editing and publishing process, as well as the fact that TOAEP's publications have frequently been linked to other CILRAP activities funded by donors, enabling CILRAP to support TOAEP's publication process. Moreover, TOAEP's system of quality control - and its expressed purpose of building global public knowledge goods in the field of international law - has attracted support from many young professionals seeking involvement in the activities of TOAEP and CILRAP.

One of the ways in which TOAEP disseminates its publications is by making its publications available through the Legal Tools Database, which is an online resource hosted by the International Criminal Court. The express goal of the Legal Tools Database, is according to its website, to 'to include [...] every legal document - international or national that a practitioner working on core international crimes cases might need. ${ }^{77}$ To this end, the Database contains primary legal documents, but it also includes a selection of publications within the field of international criminal law. In total, the database contains more than 61,000 records. ${ }^{78}$ In this way, users of the database may obtain access both to legal texts, but also potentially - publications commenting on those legal texts, through one single search query. It is important to note in this regard that as with open access repositories and archives, views and legal arguments presented in publications contained in the Legal Tools Database do not necessarily reflect the views of the International Criminal Court. The Co-ordinator of the Legal Tools Project of the International Criminal Court, who is also the founding Director of CIRAP and Editor-in-Chief of TOAEP, Morten Bergsmo, has, through a comprehensive and sustained effort in the last decade established and developed instruments of providing access

\footnotetext{
77 See <http://www.legal-tools.org/current-status-of-the-database/> accessed 1 June 2013 for more information.

78 The number of records in the database (updated twice per day) is published online, at <http://www.legal-tools.org/en/current-status-of-the-database/> accessed 1 June 2013.
} 
to knowledge and information as a global public good, and has in this respect served as a pioneer in the field of international criminal law.

\section{Open Access Policies}

Decision-makers in the world of academia, as well as and political leaders, have in recent years emphasised the benefits of open access publishing, and developed policies to encourage or require researchers to make their articles available open access. Such policy decisions may be motivated by a notion of academic duty to contribute to society and to provide a public good; by a conviction that tax-payers should be able to freely access publicly funded research; and by economic efficiency goals, as economists suggest that open access policies potentially could bring substantial net system savings in the science industry, as university libraries would not be required to pay for access to the fruits of research that has already been paid for by other public institutions. ${ }^{79}$

The Consolidated Appropriation Act of 2008 in the United States gave the National Institute of Health (NIH) a mandate to require that an electronic version of all final peerreviewed manuscripts of articles produced with $\mathrm{NIH}$ funding should be made publicly available in the PubMed Central repository. ${ }^{80}$ This policy applies to some 90,000 journal articles per year. ${ }^{81}$ Following the same principles, the Fair Access to Science and Technology Research Act (FASTR) was introduced in Congress as a bi-partisan bill in February 2013. ${ }^{82}$ If passed, the bill will introduce open access mandates applicable to research grants from

\footnotetext{
79 See John Houghton, 'Open Access - What are the Economic Benefits? A Comparison of the United Kingdom, Netherlands and Denmark' (Victoria University 2009) < http://www.knowledgeexchange.info/Files/Filer/downloads/OA_What_are_the_economic_benefits_-_a_comparison_of_UK-NLDK_FINAL_logos.pdf $>$ accessed 1 June 2013.

$80 \quad$ Full text is available at <http://www.gpo.gov/fdsys/pkg/PLAW-110publ161/pdf/PLAW110publ161.pdf> accessed 1 June 2013.

81 Letter from the director of NIH to the chairman of the US House of Representatitves Subcommittee on Health, dated 16 December 2011. Available at <http://publicaccess.nih.gov/Collins_reply_to_Pitts121611.pdf> accessed 1 June 2013

82 The full text of the proposed bill is available at <http://doyle.house.gov/sites/doyle.house.gov/files/documents/2013\%2002\%2014\%20DOYLE\%20FASTR\%20 FINAL.pdf $>$ accessed 1 June 2013.
} 
most federal agencies. Similar developments are also taking place on state level in the United States, for example by the passing of the California Taxpayer Access to Publicly Funded Research Act (AB 209) in the California House Assembly in May 2013. ${ }^{83}$

Also in 2008, the European Union launched a "pilot scheme" for open access to publications resulting from projects under its Seventh Framework Programme, across several academic disciplines. ${ }^{84}$ This scheme requires research grant recipients in some $20 \%$ of the projects supported by the Framework Programme to ensure online availability of published scientific articles that resulted from the project within six or twelve months, depending on the thematic research area. This open access policy is set to apply to all research projects under the forthcoming EU Commission framework programme for research and innovation, "Horizon 2020", which will be implemented in the period 2014-2020 with a budget of some EUR 80 billion. ${ }^{85}$ Policies of mandatory open access publishing have also been introduced on the national level in Europe and locally at academic institutions. ${ }^{86}$ Some private funders of research have also adopted open access policies, including notably the UK Wellcome Trust, which is expanding its open access policy from October 2013 to also include scholarly monographs and book chapters, in other words expanding the scope of open access beyond works that authors normally "donate" to the scientific community without expectation of remuneration. ${ }^{87}$

\footnotetext{
83 At the time of writing, the bill is set to be heard in Senate. The full text of the proposed bill is available at <http://leginfo.legislature.ca.gov/faces/billNavClient.xhtml?bill_id=201320140AB609> accessed 1 June 2013.

84 See EU Commisson decision C(2008) 4408 final.

85 European Commission, 'Proposal for a Council Decision Establishing the Specific Programme Implementing Horizon 2020 - The Framework Programme for Research and Innovation (2014-2020)', 2011/0402 (CNS).

${ }_{86} \quad$ For a survey of policies in a selection of European states, see European Commission, DirectorateGeneral for Research and Innovation, 'National Open Access and Preservation Policies in Europe: Analysis of a Questionnaire to the European Research Area Committee' (Publications Office of the European Union 2011); For a description of the Open Access policy at UiO, see Charlotte Børde, 'Open Access Policy at the University of Oslo’ (2011) Sciecom Info <http://www.sciecom.org/ojs/index.php/sciecominfo/article/view/5334> accessed 1 June 2013, see also n 58 above.

87 See <http://www.wellcome.ac.uk/About-us/Policy/Policy-and-position-statements/WTD002766.htm>.
} 
Open access policies that span across all disciplines of research, such as the open access policy in EU's Horizon 2020, and the proposed FASTR bill will not only have a direct effect on open access publishing through the requirements that are directly placed on researchers. Through an increase in the number of articles being made available through open access channels, these policies may also indirectly contribute to the development of open access publishing channels in disciplines that have so far lagged behind in this respect. As noted by Suber, in the competition between journals for the best article submissions, the prestige of the journal is one of the 'major incentives' that may lead authors to choose to submit to one journal rather than the other. ${ }^{88}$ The mainstreaming of open access publishing that policies such as FASTR and the open access requirements of Horizon 2020 entail could arguably strengthen the standing of open access publication within research communities.

According to a set of principles for university open access policies that were proposed by Suber in 2008 and have largely been heeded by policy-makers, open access policies should be aimed at the "green" route of open access by requiring that articles published in conventional journals are also made openly available through repositories, and not require publication through the "gold" route. Obliging researchers to publish in a specified and limited group of journals, could according to Suber limit 'faculty freedom'. ${ }^{89}$ Faculty freedom and scientific freedom in general is indeed an essential concern that should be taken into consideration in the development of research policy. If Horizon 2020 and the FASTR bill over time results in mainstreaming of open access principles, the impact on faculty freedom of requiring 'golden route' open access publishing could be significantly reduced.

\footnotetext{
$88 \quad$ Suber (n 38) 185.

89 Suber, 'Three Principles for University Open Access Policies' SPARC Open Access Newsletter 120 (2 April 2008) <http://www.earlham.edu/ peters/fos/newsletter/04-02-08.htm> accessed 1 June 2013.
} 


\section{Conclusion}

In sum, the article has shown through analysis of relevant human rights provisions that states have an obligation to ensure the realisation of the human right to benefit from progress in science, and that there is a developing understanding of this obligation to include the promotion of open access to scientific knowledge. Moreover, the article argues that open access dissemination of journal articles furthers the goal of providing access to scientific knowledge as a public good, and that this public good may be provided in ways that do not prejudice authors' rights to protection of their material and moral interests emanating from their creation, as provided by ICESCR article 15 . The article finally highlights some key issues in the current development of open access publishing and policies of mandatory open access publishing, including the open issue of how to ensure sustainable financing of the costs of producing high quality open access journals without relying on subscription fees, and outlines current legal developments taking place in the United States and EU.

It is recognised that there are issues in the debate on the right to science and open access that require further discussion, in particular through the clarification of the contents of the human right to science and through further development of the implementation of the principles of open access. The present contribution seeks to spur and facilitate further efforts in this regard. 